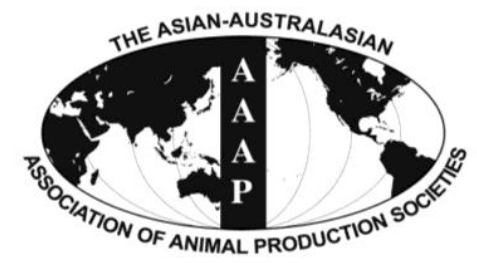

\title{
Effects of Processing of Starter Diets on Performance, Nutrient Digestibility, Rumen Biochemical Parameters and Body Measurements of Brown Swiss Dairy Calves
}

\author{
J. Ghassemi Nejad ${ }^{1}$, N. Torbatinejad ${ }^{1}$, A. A. Naserian ${ }^{2}$, S. Kumar, J. D. Kim, \\ Y. H. Song, C. S. Ra and K. I. Sung* \\ College of Animal Life System, Kangwon National University, Chuncheon, 200-701, Korea
}

\begin{abstract}
In order to investigate the effect of physical forms of starter diets on performance, weaning age, nutrient digestibility and rumen biochemical factors, 24 female of neonatal Brown Swiss calves (average body weight of $39.5 \pm 1.2 \mathrm{~kg}$ ) were randomly assigned to three treatments. Dietary treatments were mashed (MS), pelleted (PS), and texturized (TS) starter using 8 calves from birth till 90 days of age in each treatment. Diets were formulated to be iso-nitrogenous with $21 \%$ crude protein. Based on the experimental results, calves that received PS and TS diets, had significant higher average daily gain (ADG) than those receiving MS ( $p<0.01$ ). Dry matter intake in calves fed PS and TS was greater than calves fed MS ( $p<0.05)$, but there was no significant difference in feed efficiency. Treatments had no effect on initiation of rumination. Weaning age of calves in MS was longer than the other two treatments ( $p<0.05$ ). Crude protein and organic matter digestibility in MS treated calves were lower than other treatments $(\mathrm{p}<0.05)$. No differences were observed in neutral detergent fiber (NDF) and ash digestibility among treatments $(\mathrm{p}>0.05)$. Ruminal $\mathrm{pH}$ was higher $(\mathrm{p}<0.01)$ in MS than the other groups, but ruminal ammonia $(\mathrm{g} / \mathrm{dl})$ concentration was not different among the treatments. Body measurements such as body length, pin width, hip width, pin to hip length, size of metacarpus and metatarsus bones, hip height, wither height, stomach size and heart girth were not significantly different among the treatments. Overall, it is concluded that starter diets in the form of pellet and texture can improve performance in neonatal Brown Swiss calves compared to the mashed form. (Key Words: Brown Swiss Calves, Mash, Processing, Pellet, Starter Diet, Texture)
\end{abstract}

\section{INTRODUCTION}

Comprehensive research has evaluated several methods for feed processing to improve its utilization by mono and poly-gastric animals. Appropriate time for weaning of calves is very important to prevent loss in their performance and healthiness. According to Abdelgadir and Morrill (1995) feed processing, which disrupts the structure of starch and the union between protein and starch in the grain endosperm, may improve digestibility. Till date, few studies have examined the effect of processing of calf starters with

\footnotetext{
* Corresponding Author: KyungIl Sung. Department of Animal Life System, Kangwon National University, Chunchon 200-701, Korea. Tel: +82-33-250-8635, Fax: +82-33-242-4540, E-mail: kisung@kangwon.ac.kr

${ }^{1}$ Department of Animal Science, Gorgan University of Agricultural Sciences and Natural Resources, Iran.

2 Department of Animal Science, Ferdowsi University of Mashhad, Iran.

Submitted Dec. 1, 2011; Accepted Feb. 10, 2012; Revised Apr. 16, 2012
}

and without forage on intake, performance, and weaning age. Earlier studies (Warner et al., 1973; Warner, 1991) reported that the ingredients of calf starters should not be finely grounded and at least $50 \%$ of the particles should be larger than 1,190 $\mu \mathrm{m}$. However, recent study (Bateman et al., 2009) concluded that fine grinding increases the surface area of the grain and the potential attachment sites for microbes or enzymes. Franklin et al. (2003) weaned calves when their starter consumption became greater than 0.68 $\mathrm{kg} / \mathrm{d}$ for $2 \mathrm{~d}$ consecutively. Calves fed textured starter consumed more total grain, were weaned earlier, and gained more weight at $6 \mathrm{wk}$ of age than calves fed pelleted starter. Coverdale et al. (2004) started weaning when all calves were consuming $450 \mathrm{~g}$ of starter with and without forage on $52 \mathrm{~d}$ of the trial. Calves fed coarse starter with $7.5 \%$ and $15 \%$ of brome grass hay in their ration had greater body weight (BW) and feed efficiency than those receiving commercial coarse and ground starter. Studies investigating the use of forage in starter diets have reported inconsistent 
results. Several researchers concluded that forage addition to the ration increases DMI (Kincaid, 1980; Thomas and Hinks, 1982; Stobo et al., 1985). However, others have seen a negative impact of forage addition on the consumption of starter diets (Hibbs et al., 1956; Whitaker et al., 1957; Leibholz, 1975). Bach et al. (2007) reported that the efficiency gain was better with a pellet diet than a mash diet and the intake was lower in the mash diet than in a pellet diet in post-weaning calves. In contrast, Beharka et al. (1998) observed that calves fed with a ground diet had higher BW than those fed with an unground diet. Ruminal $\mathrm{pH}$ was lower in calves fed ground diets $(1 \mathrm{~mm})$ than that of the ones fed unground diets $(0.64 \mathrm{~cm})$. Diets that are chopped or ground to fine particle sizes decrease rumen $\mathrm{pH}$ and cellulolytic bacteria populations. However, in Beharka et al. (1998) study the ground diet did contain $25 \%$ alfalfa hay. Owen and Larson (1986) compared intake of calves fed starter as a meal form with the same mix in pelleted form and did not find difference in starter intake or performance. Some experiments have been carried out to investigate the effects of the form of starter with or without forage of different particle sizes and to find the proper consumption of starter on weaning age, BW, DMI. However, it seems that more studies are required to find less equivocal results on performance of dairy calves. Moreover, very few studies have been conducted on Brown Swiss dairy calves. Therefore, the objective of this study was to compare the weaning age and performance of dairy Brown Swiss calves fed with mashed, pelleted, and textured starters.

\section{MATERIALS AND METHODS}

Twenty-four female Brown Swiss calves with an average initial body weight of $39.5 \pm 1.2 \mathrm{~kg}$ were assigned to three treatments commencing from birth until 90 days of age. The treatments included mashed (particle size of 0.7 $\mathrm{mm}$ diameter, MS), pelleted (4 $\mathrm{mm}$ diameter, PS), and textured starters (rolled corn and barley with other ingredients in the form of pellet of $4 \mathrm{~mm}$ diameter, TS). The MS used was finely ground calf starter ration without forage. The PS and TS were commercial type of starters without forage. All starters were processed using steam and 75 to $80^{\circ} \mathrm{C}$ temperature. Calves were weighed and assigned to treatments 3 days after birth and the ration used in this trial was according to NRC requirements for dairy animals (2001) as shown in Table 1. Based on common on-farm procedures, all calves received milk at 10 percent of initial body weight till weaning age. For the first 3 days they received colostrum at 10 percent of initial body weight. Calves were housed in individual hutches $(1.2 \times 2.4 \mathrm{~m}$ individual pens) bedded with a pad. Water was available $\mathrm{ad}$ libitum.

All starters were formulated to be iso-nitrogenous with $21 \%$ CP. Chemical composition of the starters is shown in Table 1. Starter intake was determined daily, and body weights were recorded every $2 \mathrm{wks}$, for period 1 ( 0 to $15 \mathrm{~d}$ ), period 2 ( 15 to $30 \mathrm{~d}$ ), period 3 ( 30 to $45 \mathrm{~d}$ ), period 4 ( 45 to $60 \mathrm{~d}$ ), period 5 (60 to $75 \mathrm{~d}$ ), and period 6 (75 to $90 \mathrm{~d}$ ). Weaning occurred according to starter intake by individual calves (consumed $0.9 \mathrm{~kg}$ of starter/day for 3 days, consecutively). Mean age at weaning was 52.17, 43.0, and $41.33 \mathrm{~d}$ for calves fed MS, PS, and TS, respectively.

\section{Sample collection and analysis}

Rumen fluid samples were collected via a stomach tube at $11 \mathrm{AM}$ every $2 \mathrm{wks}$ at day 15, 30, 45, 60, 75, and 90 of the study. After measuring ruminal fluid $\mathrm{pH}$, fluid was strained and immediately frozen using dry ice and stored $\left(-20^{\circ} \mathrm{C}\right)$ until further analysis for $\mathrm{NH}_{4}-\mathrm{N}$. Body weight gains were measured every two wks. Amount of starter and milk consumption offered and refused were recorded daily. Feed and fecal samples were collected for 5 days after weaning

Table 1. Ingredients and analyzed chemical composition of starters

\begin{tabular}{|c|c|c|c|c|c|c|}
\hline Ingredients & Percent $(\%)$ & Nutrients (\% of DM) & Mash starter & Pellet starter & Texture starter & SE \\
\hline Corn & 25 & Dry matter & 91.0 & 91.5 & 89.9 & 1.56 \\
\hline Barley & 23 & Crude protein & 20.5 & 21.4 & 21.1 & 1.16 \\
\hline Soybean meal & 20 & Acid detergent fibre & 6.4 & 6.2 & 6.1 & 1.01 \\
\hline Cotton seed meal & 14 & Neutral detergent fibre & 13.5 & 13.3 & 13.1 & 1.20 \\
\hline Fish meal & 2 & Calcium & 1.3 & 1.32 & 1.2 & 0.15 \\
\hline Molasses & 5 & Phosphorous & 0.81 & 0.76 & 0.83 & 0.08 \\
\hline Wheat bran & 7.4 & Organic matter & 91.2 & 91.7 & 92.1 & 1.07 \\
\hline Sodium bicarbonate & 0.05 & ME* (Mcal/kg) & 2.45 & 2.51 & 2.53 & 0.11 \\
\hline Calcium carbonate & 1.3 & & & & & \\
\hline Calcium phosphate & 0.3 & & & & & \\
\hline Magnesium oxide & 0.2 & & & & & \\
\hline Mineral-vitamin supplement & 1 & & & & & \\
\hline Salt & 0.3 & & & & & \\
\hline
\end{tabular}

* Metabolizable energy. 


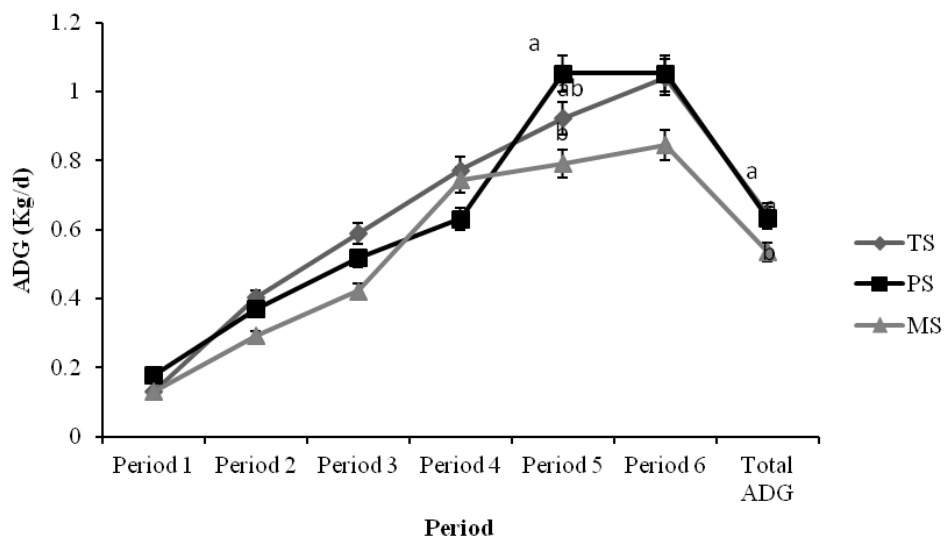

Figure 1. Average daily gain in calves fed three forms of starters. Data points with different letters differ significantly $(\mathrm{p}<0.05)$. $p$ values for treatment, time and treatment $\times$ time were $0.0026,<0.0001$, and 0.1006 , respectively.

for evaluating nutrient digestibility (AOAC, 1990). The rest of feed was collected and weighed every day at $8 \mathrm{AM}$ in the morning for each calf separately for 5 days. All feces were collected and weighed at 8:30 AM during these 5 days after weaning. Then all the feed samples for each calf were mixed together, sample was taken and stored $\left(-20^{\circ} \mathrm{C}\right)$ for further analysis. The fecal collections for each calf were also mixed together and a sample stored at $-20^{\circ} \mathrm{C}$ for later analysis.

Body measurements of each calf including body length, pin width, hip width, pin to hip length, metacarpus size, metatarsus size, hip height, wither height, stomach size and heart girth measured with calipers every two wks. Initiation of rumination was recorded by watching calves every day.

\section{Statistical analysis}

Data for intake, growth, nutrients digestibility, and rumen biochemical parameters were analyzed in a completely randomized design. A repeated measures analysis was conducted by using the MIXED procedure of SAS (SAS Institute, 1999) and the means were compared for significance by Tukey's test (Snedecor and Cochran, $1967)$ at $\mathrm{p}<0.05$. Initial body weight as a covariate was included in the model when appropriate but was removed from the model when not significant. The statistical model used for analyses was:

$$
\mathrm{Y}_{\mathrm{ijkl}}=\mu+\alpha_{\mathrm{i}}+\mathrm{d}_{\mathrm{ij}}+\mathrm{W}_{\mathrm{k}}+\mathrm{T}_{\mathrm{l}}+(\alpha \mathrm{T})_{\mathrm{il}}+\mathrm{e}_{\mathrm{ijkl}}
$$

Where, $\mathrm{Y}_{\mathrm{ij \textrm {jl }}}=$ the observation for trait, $\mu=$ overall mean, $\alpha_{i}=$ the effect of treatment, $d_{i j}=$ random effect of treatment $\times$ animal, $\mathrm{W}_{\mathrm{k}}=$ initial body weight, $\mathrm{T}_{1}=$ the effect of time, $(\alpha \mathrm{T})_{\mathrm{il}}=$ interaction of treatment $\times$ time, and $\mathrm{e}_{\mathrm{ijkl}}=$ the residual effect.

Variance and covariance assumption structures $(\operatorname{AR}(1)$, $\mathrm{UN}, \mathrm{CS}$, etc) were tested, then $\mathrm{AR}(1)$ as the best covariance structure for final analysis was selected.

\section{RESULTS AND DISCUSSION}

\section{Effects of treatments on average daily gain}

Average daily gain (ADG) for the whole period was affected by treatments $(p<0.01)$ and a significant increase in calves fed with the PS and TS diets in comparison with MS (Figure 1) was observed. No difference was noticed in ADG in all the treatments prior to weaning (as weaning occurred in period 3 to 4 for all treatments). In accordance with our results previous reports (Church, 1986), have shown that starter ingredient composition, processing of diet and changing the particle size can affect some production traits and performance of animals. Furthermore, the organic matter and crude protein digestibility in calves fed with PS and TS were higher than MS (Table 2). Calves fed with TS and PS consumed more DMI and gained more weight compared to calves receiving MS. Lassiter et al. (1955), Gardner (1967), and Kertz et al. (1979) all have reported that calves consume less starter of fine particle size than of large particle size.

There are research articles that compared form and particle size of starters for calves (Franklin et al., 2003; Coverdale et al., 2004; Bach et al., 2007; Porter et al., 2007)

Table 2. Nutrients digestibility comparison of calves fed three forms of starters ${ }^{1}$

\begin{tabular}{lcccc}
\hline $\begin{array}{l}\text { Nutrients } \\
(\%)\end{array}$ & \multicolumn{3}{c}{ Treatments } & \multirow{2}{*}{ SE } \\
\cline { 2 - 4 } & MS & PS & TS & \\
\hline DM & $75.0^{\mathrm{b}}$ & $81.1^{\mathrm{ab}}$ & $82.1^{\mathrm{a}}$ & 1.82 \\
$\mathrm{CP}$ & $68.1^{\mathrm{b}}$ & $72.2^{\mathrm{a}}$ & $72.6^{\mathrm{a}}$ & 0.81 \\
$\mathrm{OM}$ & $78.6^{\mathrm{b}}$ & $85.0^{\mathrm{a}}$ & $86.6^{\mathrm{a}}$ & 1.62 \\
$\mathrm{ADF}$ & $39.5^{\mathrm{a}}$ & $35.6^{\mathrm{ab}}$ & $33.3^{\mathrm{b}}$ & 1.42 \\
NDF & 45.6 & 41.8 & 40.6 & 1.41 \\
\hline
\end{tabular}

${ }^{1}$ Values with different superscripts in the same row differ significantly $(\mathrm{p}<0.05)$. 


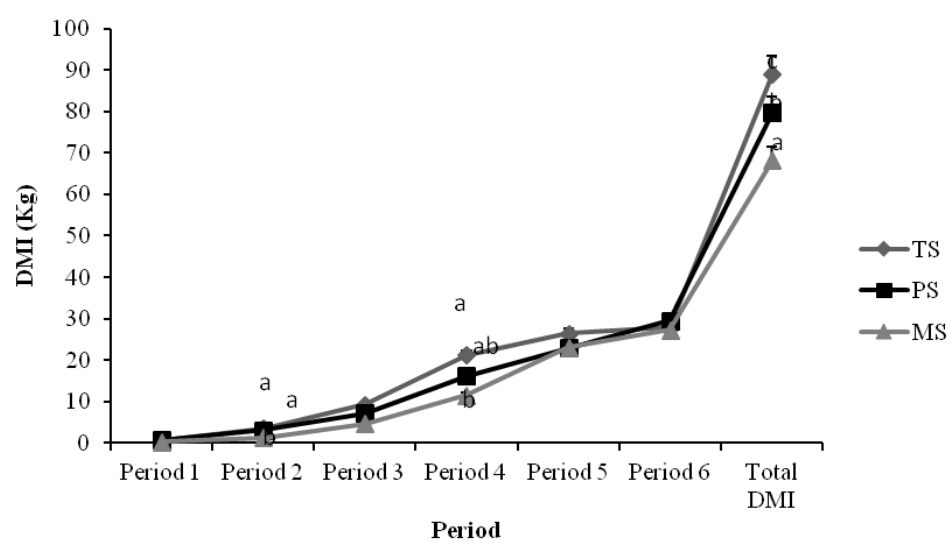

Figure 2. Dry matter intake in calves fed three forms of starters. Data points with different letters differ significantly ( $p<0.05)$. $p$ values for treatment, time and treatment $\times$ time were $0.04018,<0.0001$, and 0.1016 , respectively.

and each of these can be criticized for various reasons that confounded interpretation of their results. Franklin et al. (2003) reported less pre-weaning starter intake and ADG in calves fed pelleted starter; however, starters were not equal in $\mathrm{CP}$, additives, molasses, protein sources, and several other ingredients and nutrients. Bach et al. (2007) fed pelleted or coarse mash to calves and reported better efficiency of gain but lower starter intake with a pelleted diet in post-weaning than mash starter. However, Kertz (2007) criticized the study for not discussing the impact of bedding consumption by the calves fed with pelleted diet. Porter et al. (2007) reported greater ADG in neonatal calves fed a coarse meal diet compared to a fine ground diet that had been pelleted.

Chester-Jones and Ziegler (1994) investigated effects of whole, pelleted and rolled corn grain on performance of beef steers and indicated that whole and pelleted corn grain increases steer performance during the growth period. Coverdale et al. (2004) reported a greater increase in weight after weaning in calves fed with a coarse starter than those fed with a ground starter. These results conflict with those observed by Beharka et al. (1998) who observed greater $\mathrm{BW}$ in calves fed a ground diet offered in restricted amounts versus an unground diet of identical composition.

\section{Effects of treatments on DMI and FE}

There were significant differences among calves offered diets PS, TS and MS in dry matter intake (DMI) over the entire trial $(\mathrm{p}<0.05)$. Mean total DMI was 68.14, 79.61, and $89 \mathrm{~kg}(\mathrm{SE}=3.04)$ for calves fed MS, PS, and TS, respectively. In addition, as shown in Figure 2 in period 2 and 4, the mean DMI illustrated some differences between treatments. However, there were no differences in feed efficiency (FE) prior to and after weaning whereas the total FE was 2.77, 2.48, and $2.53 \pm 0.41$ in MS, PS and TS, respectively.
Franklin et al. (2003) reported that the total DMI in a group of calves fed with textured starter was higher than ground starter or pelleted starter but they indicated that this difference might be explained by an earlier weaning age in the texture starter treatment. Furthermore, $\mathrm{CP}$ in the textured starter was higher than the others in their study. Because of these two reasons calves in the textured treatment consumed more DMI than the other treatments. Rooney and Pflugfelder (1986) indicated that feed in the form of ground particles (fine particle size) causes more dust and can decrease feed intake. Similarly, we found a lower feed intake in the MS treatment than TS and PS because it was finely ground (Figure 2).

Grimson et al. (1987) and Mathison et al. (1997) reported no difference in FE in steer fed with rolled and moisten barley compared to those fed with ground barley. Porter et al. (2007) reported a greater starter intake in neonatal calves fed a coarse meal diet compared to a fine ground diet that had been pelleted.

Moreover, our results of FE are accordance with the results of Coverdale et al. (2004) and Samanta et al. (2003). They both reported that there were no significant decreases in FE in calves and goats fed with coarse starter and blocked feed during and at the end of the trials, respectively.

\section{Effect of treatments on rumen fluid}

Significant effects in $\mathrm{pH}$ were observed in period 4, and 6 of the study (Figure 3). During period 4 rumen $\mathrm{pH}$ was significantly lower in calves that received PS or TS starter than in calves that received MS $(p<0.01)$ while there was no difference in calves fed with TS or PS. In period 6 calves fed with TS showed a lower $\mathrm{pH}(\mathrm{p}<0.01)$ than calves fed with MS and there were no significant difference between calves in PS and MS. Moreover, no difference was found between calves fed with PS and TS (Figure 3).

During period 5 rumen ammonia-N was significantly 


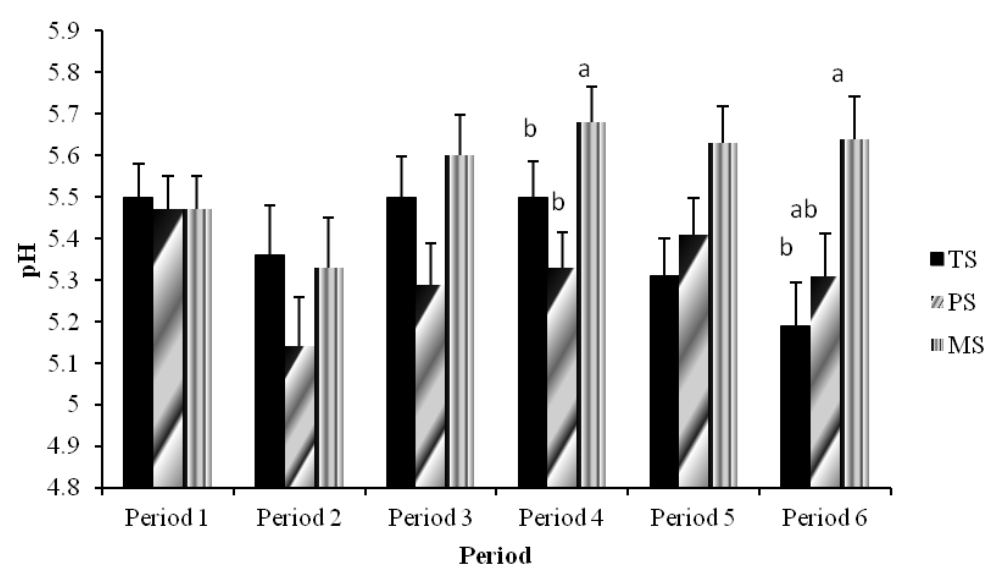

Figure 3. Rumen fluid $\mathrm{pH}$ in calves fed three forms of starters. Bars with different letters differ significantly ( $\mathrm{p}<0.05$ ). $\mathrm{p}$ values for treatment, time and treatment $\times$ time were $0.0003,0.0673$, and 0.2462 , respectively.

higher $(\mathrm{p}<0.05)$ in the MS group, while there was no difference between the TS and PS groups. There were no differences between treatments during the other periods (Figure 4). Larger particle size increases ruminal salivary flow through greater initial mastication and subsequent rumination in mature and immature ruminants and more urea released through saliva can cause this increase in $\mathrm{NH}_{4}-\mathrm{N}$ (Hibbs et al., 1956; Beauchemin et al., 2001). Furthermore, increasing starch digestibility by increasing processing level may be advantageous in neonatal calf growth.

Higher rumen $\mathrm{pH}$ in calves fed MS may indicate a moderate buffering effect of unprocessed grains when concentrates are fed in high proportion. Similar processing effects on rumen $\mathrm{pH}$ were reported by Murphy et al. (1994) who found a decreased ruminal $\mathrm{pH}$ in feedlot steers fed diets containing dry-rolled corn. Conversely, a possible negative relationship between processing level and rumen $\mathrm{pH}$ may decrease rumen development or epithelial absorptive ability (Bull et al., 1965; Hinders and Owen,
1965; Anderson et al., 1982). Different corn processing levels can be found in commercially available calf starters. However, adult ruminants, especially lactating cows, typically receive diets containing forage and/or rumen buffers, possibly hiding any effect of grain processing on rumen $\mathrm{pH}$. On the contrary, calves in the current study did not receive forages in their diets similar to the experiment of Franklin et al. (2003); therefore, feed materials entering the rumen are primarily consisting of rapidly degradable concentrates. There are not many differences in rumen $\mathrm{pH}$ in the current study.

Crocker et al. (1998) reported rumen ammonia-N decreased as steam flaked corn replaced dry-rolled corn. They attributed this effect to increase microbial utilization of available ammonia-N. In addition, others have reported a tendency for decreasing rumen ammonia- $\mathrm{N}$ as starch degradability increases (Russell et al., 1983; Aldrich et al., 1993; Knowlton et al., 1998). Conversely, Joy et al. (1997) and Murphy et al. (1994) found no influence of grain processing on rumen ammonia-N concentrations when

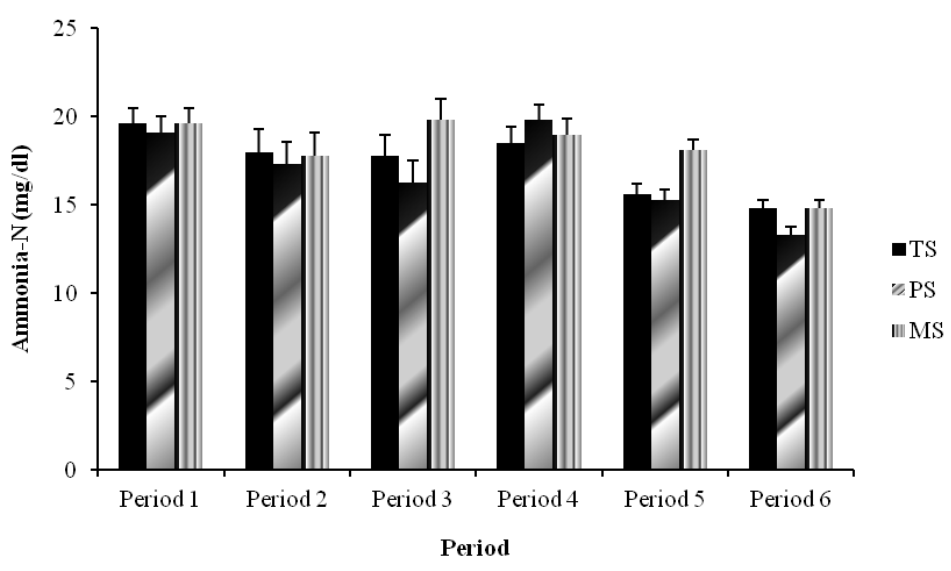

Figure 4. Rumen fluid ammonia- $\mathrm{N}$ in calves fed three forms of starters. $\mathrm{p}$ values for treatment, time and treatment $\times$ time were 0.0676 , $<0.0001$, and 0.5734 , respectively. 
compared with steam-flaked, dry-rolled, and whole corn in mature ruminants. Rumen ammonia-N did appear to decrease as starter intake increased in our study. This indicates ruminal microbial proliferation and increasing utilization of ammonia-N for microbial protein synthesis (MCP). However, microbial counts were not conducted in the current study.

\section{Apparent nutrients digestibility}

Means of apparent nutrients digestibility (\%) including DM, CP, OM, ADF, and NDF are presented in Table 2. Dry matter (DM) digestibility in calves that received MS was lower than TS treatment $(\mathrm{p}<0.05)$ but no differences were observed between TS and PS treatments. Crude protein (CP) digestibility in the MS treatment was lower than the other two treatments $(\mathrm{p}<0.05)$ but there was no significant difference between PS and TS treatments. As with CP, similar results were observed for organic matter digestibility $(\mathrm{OM})$. There were no significant differences between treatments for NDF digestibility.

Changes in the rumen environment have been reported due to altered physical and chemical characteristics of processed grains and concomitant changes in digestibility (Lesmeister and Heinrichs, 2005). Cereal grains are often processed before feeding to increase digestion of the starch and other nutrients. Steam flaking and roasting gelatinizes the starch of corn, thus increasing the ability of microbes and enzymes to hydrolyze the starch granule. Fine grinding increases the surface area of the grain, thus increasing the potential attachment sites for microbes or enzymes. However, reports on improvement in calf growth are limited when processed grains are fed (Bateman et al., 2009).

Differences in DM or OM digestibilities with different processing methods have also been reported. Yu et al. (1998) indicated that there was a decrease in dietary OM digestibility with differently processed corn, in the order of steam-rolled, finely ground, dry-rolled, with steam-flaked having the lowest dietary OM digestibility. Murphy et al. (1994) indicated that dry rolling corn increased DM and OM digestibility over whole corn when the intake was limited. Additionally, others have reported that the processing method did not influence DM digestibility (Joy et al., 1997; Crocker et al., 1998). Our results are in parallel with the study of Bradshow et al. (1996) that indicated higher digestibility of barley by introducing moisture into the grain processing when it was fed to beef steers. Lower value of NDF and ADF digestibilities can be explained by the increase in DMI of PS and TS.

\section{Effects of treatments on weaning age, initiation of rumination and body measurements}

Initiation of rumination was first in calves fed with MS and last in PS, however these differences were not
Table 3. Initiation of rumination and weaning age in calves fed three forms of starters ${ }^{1}$

\begin{tabular}{lcccc}
\hline \multirow{2}{*}{ Item (d) } & \multicolumn{3}{c}{ Treatments } & \multirow{2}{*}{ SE } \\
\cline { 2 - 4 } & MS & PS & TS & \\
\hline $\begin{array}{c}\text { Initiation of } \\
\text { rumination }\end{array}$ & 24.0 & 20.8 & 22.6 & 2.04 \\
\begin{tabular}{l} 
Weaning age \\
\hline
\end{tabular} & $52.1^{\mathbf{a}}$ & $43.0^{\mathbf{b}}$ & $41.3^{\mathbf{b}}$ & 2.51 \\
\hline
\end{tabular}

Values with different superscripts in the same row differ significantly $(\mathrm{p}<0.05)$.

significant (Table 3). Delay in the initiation of rumination in calves fed with PS may be because the calves naturally tended to prefer coarse starter compared to ground starter. Porter et al. (2007) reported an earlier time of rumination in neonatal calves fed with coarse meal diet versus a fine ground diet that had been pelleted.

Weaning age in calves fed with TS and PS was lower than the ones fed with MS (almost 10 to 11 days earlier). A decrease in weaning age has many advantages such as reducing milk consumption and decreasing labor and ration costs. Reduction in weaning age is the aim of most studies on calves and lambs. Weaning age can be lowered due to the effects of the physical form of PS and TS leading to a higher DMI and thus gaining more weight. Franklin et al. (2003) found similar results on the difference of weaning age in calves fed with TS compared to calves fed with PS, but they found no differences between calves fed with MS and PS. Coverdale et al. (2004) reported no differences in weaning age between calves fed with different kinds of starter. Porter et al. (2007) reported earlier initiation of rumination in neonatal calves fed coarse meal diet compared to a fine ground diet that had been pelleted. Body measurements including body length, pin width, hip width, pin to hip length, metacarpus size, metatarsus size, hip height, wither height, stomach size and heart girth were not significantly different among treatments (Table 4). These results were very similar to the results of the Bateman et al. (2009) that found no differences in hip width during days 0

Table 4. Body measurements of calves fed on three forms of starters (in cm)

\begin{tabular}{lrrrl}
\hline \multirow{2}{*}{$\begin{array}{l}\text { Body } \\
\text { measurements }\end{array}$} & \multicolumn{3}{c}{ Treatments } & \multirow{2}{*}{ SE } \\
\cline { 2 - 4 } Body length & 20.2 & 22.4 & 21.2 & 2.0 \\
Heart girth & 21.0 & 23.2 & 22.2 & 1.0 \\
Metacarpus size & 1.8 & 1.8 & 2.2 & 0.2 \\
Metatarsus size & 1.9 & 1.5 & 1.8 & 0.3 \\
Wither height & 15.4 & 15.5 & 14.2 & 1.1 \\
Hip height & 15.7 & 16.2 & 14.0 & 1.3 \\
Hip width & 7.3 & 8.2 & 8.3 & 0.9 \\
Pin width & 1.9 & 2.3 & 2.0 & 0.2 \\
Pin to hip length & 8.0 & 8.3 & 7.9 & 0.9 \\
Stomach size & 35.6 & 40.3 & 38.1 & 3.8 \\
\hline
\end{tabular}


to 28,28 to 56 , and 0 to 56 in calves fed with PS, TS and grounded starter.

\section{CONCLUSIONS}

This study illustrates that the form of the diet offered regarding different particle sizes may influence intake and growth of calves. It is concluded that the physical form of starter can affect calves performance; however, starter diet in the form of pellet and texture can improve performance in neonatal Brown Swiss calves compared to those on a mash diet.

\section{ACKNOWLEDGEMENTS}

The authors thank Rooholla Musavi, Behnam Saremi and Alireza Foroughi for the assistance in the farm and the laboratory.

\section{REFERENCES}

Abdelgadir, I. E. O. and J. L. Morrill. 1995. Effect of processing sorghum grain on dairy calf performance. J. Dairy Sci. 78:2040-2046.

Aldrich, J. M., L. D. Muller, G. A. Varga and L. C. Griel Jr. 1993. Nonstructural carbohydrate and protein effects on rumen fermentation, nutrient flow, and performance of dairy cows. J. Dairy Sci. 76:1091-1105.

Anderson, M. J., M. Khoyloo and J. L. Walters. 1982. Effect of feeding whole cottonseed on intake, body weight, and reticulorumen development of young Holstein calves. J. Dairy Sci. 65:764-772.

Association of Official Analytical Chemists (AOAC). 1990. 13th edition. Pubic. By AOAC, P.O.B. Box 54, Washington, DC, USA.

Bach, A., A. Gimenez, J. L. Juaristi and J. Ahedo. 2007. Effects of physical form of a starter for dairy replacement calves on feed intake and performance. J. Dairy Sci. 90:3028-3033.

Bateman, H. G., T. M. Hill, J. M. Aldrich and R. L. Schlotterbeck. 2009. Effects of corn processing, particle size, and diet form on performance of calves in bedded pens. J. Dairy Sci. 92:782789.

Beauchemin, K. A., W. Z., Yang and L. M. Rode. 2001. Effects of barley grain processing on the site and extent of digestion of beef feedlot finishing diets. J. Anim. Sci. 79:1925-1936.

Beharka, A. A., T. G. Nagaraja, J. L. Morrill, G. A. Kennedy and R. D. Klemm. 1998. Effects of form of the diet on anatomical, microbial, and fermentative development of the rumen of neonatal calves. J. Dairy Sci. 81:1946-1955.

Bradshow, W. L., D. D. Hinman, R. C. Bull, D. O. Everson and S. J. Sorensen. 1996. Effects of barley variety and processing methods on feedlot steer performance and carcass characteristics. J. Anim. Sci. 74:18-24.

Bull, L. S., L. J. Bush, J. D. Friend, B. Harris Jr. and E. W. Jones. 1965. Incidence of ruminal parakeratosis in calves fed different rations and its relation to volatile fatty acid absorption. J. Dairy Sci. 48:1459-1466
Chester-Jones, H. and D. M. Ziegler. 1994. Feeding whole or rolled corn with pelleted supplement to Holstein steers from weaning to 190 Kilograms. J. Dairy Sci. 74:1765-1771.

Church, D. C. 1986. Livestock feeds and feeding, second edition, Prentice Hall, Inc. Englewood Cliffs, New Jersey. p. 549.

Coverdale, J. A., H. D. Tyler, J. D. Quigley and J. A. Brumm. 2004 Effect of various levels of forage and form of diet on rumen development and growth in calves. J. Dairy Sci. 87:2554-2562.

Crocker, L. M., E. J. DePeters, J. G. Fadel, H. Perez-Monti, S. J. Taylor, J. A. Wyckoff and R. A. Zinn. 1998. Influence of processed corn grain in diets of dairy cows on digestion of nutrients and milk composition. J. Dairy Sci. 81:2394-2407.

Franklin, S. T., D. M. Amaral-Phillips, J. A. Jackson and A. A. Campbell. 2003. Health and performance of Holstein calves that suckled or were hand-fed colostrum and were fed one of three physical forms of starter. J. Dairy Sci. 86:2145-2150.

Gardner, R. W. 1967. Acceptability and nutritional response comparisons between calf starters. J. Dairy Sci. 50:729-734.

Grimson, R. E., R. D. Wiesenberger, J. A. Basarab and R. P. Stillborn. 1987. Effects of barley volume weight and processing method on feedlot performance of finishing steers. Can. J. Anim. Sci. 67:43-53.

Hibbs, J. W., H. R. Conrad, W. D. Pounden and N. Frank. 1956. Ahigh roughage system for raising calves based on early development of rumen function. VI. Influence of hay to grain ration on calf performance, rumen development, and certain blood changes. J. Dairy Sci. 39:171-179.

Hinders, R. G. and F. G. Owen. 1965. Relation of ruminal parakeratosis development to volatile fatty acid absorption. J. Dairy Sci. 48:1069-1073.

Joy, M. T., E. J. DePeters, J. G. Fadel and R. A. Zinn. 1997. Effects of corn processing on the site and extent of digestion in lactating cows. J. Dairy Sci. 80:2087-2097.

Kertz, A. F. 2007. Letter to the editor: Pelleted calf starter with straw access can confound results: A comment on Bach et al. (2007). J. Dairy Sci. 90:4924.

Kertz, A. F., L. R. Prewitt and J. P. Everett Jr. 1979. An early weaning calf program: Summarization and review. J. Dairy Sci. 62:1835-1843.

Kincaid, R. L. 1980. Alternate methods of feeding alfalfa to calves. J. Dairy Sci. 63:91-94.

Knowlton, K. F., B. P. Glenn and R. A. Erdman. 1998. Performance, ruminal fermentation, and site of starch digestion in early lactation cows fed corn grain harvested and processed differently. J. Dairy Sci. 81:1972-1984.

Lassiter, C. A., T. W. Denton, L. D. Brown and J. W. Rust. 1955. The nutritional merits of pelleting calf starters. J. Dairy Sci. 38:1242-1245.

Leibholz, J. 1975. Ground roughage in the diet of the earlyweaned calf. Anim. Prod. 20:93-100.

Lesmeister, K. B. and A. J. Heinrichs. 2005. Effects of adding extra molasses to a texturized calf starter on rumen development, growth characteristics, and blood parameters in neonatal dairy calves. J. Dairy Sci. 88:411-418.

Mathison, G. W., R. Hironka, B. K. Kerrigan, I. Vlach, I. P. Milligan and R. D. Weisengurger. 1997. Rate of starch degradation, apparent digestibility and rate and efficiency of steer gain as influenced by barley grain volume weight and processing method. Can. J. Anim. Sci. 71:867-878. 
Murphy, T. A., F. L. Fluharty and S. C. Loerch. 1994. The influence of intake level andcorn processing on digestibility and ruminal metabolism in steers fed allconcentrate diets. J. Anim. Sci. 72:1608-1615.

Owen, F. G. and L. L. Larson. 1986. Effect of probiocin and starter preparation on calf performance. Coop. Ext. Ser. Univ. Nebr. 1986:36-37.

Porter, J. C., R. G. Warner and A. F. Kertz. 2007. Effect of fiber level and physical form of starter on growth and development of dairy calves fed no forage. Prof. Anim. Sci. 23:395-400.

Rooney, L. W. and R. L. Pflugfelder. 1986. Factors affecting starch digestibility with special emphasis on sorghum and corn. J. Anim. Sci. 63:1607-1623.

Russell, J. B., C. J. Sniffen and P. J. Van Soest. 1983. Effects of carbohydrate limitation on degradation and utilization of casein by mixed rumen bacteria. J. Dairy Sci. 66:763-775.

Samanta, A. K., K. K. Singh, M. M. Das, S. B. Maity and S. S. Kundu. 2003. Effect of complete feed block on nutrient, utilization and rumen fermentation in Barbari goats. Small Rumin. Res. 48:95-102.

SAS. 1999. SAS/STAT user's guide (Version 8.01 Edition). SAS Inst. Inc., Cary, NC, USA.
Snedecor, G. W. and W. G. Cochran. 1967. Statistical Methods (6th Ed.). Iowa State Univ. Press, Ames.

Stobo, I. J. F., C. S. Lucci, J. H. B. Roy and M. W. Perfitt. 1985. Comparison of high-energy pellets containing processed fibre with a coarse concentrate mixture in relation to the development of solid food intake in the calf. Anim. Prod. 40:570.

Thomas, D. B. and C. E. Hinks. 1982. The effect of changing the physical form of roughage on the performance of the earlyweaned calf. J. Anim. Prod. 35:375-384.

Warner, R. G. 1991. Nutritional factors affecting the development of a functional ruminant-A historical perspective. Proc. Cornell Nutr. Conf., 1-12. Ithaca, NY: Cornell University.

Warner, R. G., J. C. Proter and S. T. Slack. 1973. Calf starter formulation for neonatal calves fed no hay. Proc. Cornell Nutr. Cornell University, Ithaca.

Whitaker, R. T., W. J. Miller, J. L. Carmon and H. L. Dalton. 1957. Influence of level and source of crude fiber in calf starters on weight and feed consumption. J. Dairy Sci. 40:887-892.

Yu, P., J. T. Huber, F. A. P. Santos, J. M. Simas and C. B. Theurer. 1998. Effects of ground, steam-flaked, and steam-rolled corn grains on performance of lactating cows. J. Dairy Sci. 81:777783. 